\title{
Nomenclatural changes in Zingiberaceae: Haplochorema is reduced to Boesenbergia
}

\author{
J.D. Mood ${ }^{1}$, M. Ardiyani², †J.F. Veldkamp ${ }^{3}$, T. Mandáková ${ }^{4}$, \\ L.M. Prince ${ }^{5} \&$ H.J. de Boer $^{3,6}$ \\ ${ }^{1}$ Lyon Arboretum, University of Hawaii, 3860 Manoa Road, \\ Honolulu, Hi 96822, USA \\ ${ }^{2}$ Herbarium Bogoriense, Research Center for Biology, Indonesian Institute of Sciences \\ (LIPI), Cibinong Science Center, Jl., Raya Bogor Km 46, Cibinong, Indonesia 16912 \\ ${ }^{3}$ Naturalis Biodiversity Center, Section Botany, P.O. Box 9514, \\ 2300 RA Leiden, The Netherlands \\ ${ }^{4}$ CEITEC - Central European Institute of Technology, and Faculty of Science, \\ Masaryk University, Kamenice 5, 62500 Brno, Czech Republic \\ ${ }^{5}$ The Field Museum, Department of Botany, 1400 S Lake Shore Dr., \\ Chicago, IL 60605, USA \\ ${ }^{6}$ Natural History Museum, University of Oslo, Postboks 1172, \\ Blindern, 0318 Oslo, Norway \\ h.de.boer@nhm.uio.no
}

\begin{abstract}
The history of Haplochorema K.Schum. (Zingiberaceae) is reviewed, its morphology is compared to Boesenbergia Kuntze and the molecular phylogenetic position is shown in relation to other Zingiberaceae. Based on a comparative analysis of molecular and morphological data, Haplochorema is reduced to Boesenbergia with eight new combinations. A lectotype for Boesenbergia loerzingii (Valeton) K.Larsen ex M.F.Newman, Lhuillier \& A.D.Poulsen is designated here.
\end{abstract}

Keywords. Borneo, Gastrochilus, Kaempferia, lectotypes, molecular phylogeny, nomenclature, taxonomy

\section{Introduction}

Since 2010, molecular data from both nuclear ITS and the chloroplast trnK intron have been collected to infer a phylogeny of Boesenbergia Kuntze. In the course of enquiry over 50 Boesenbergia species have been included along with various species of about 27 other genera. In this overall analysis, a sample of Haplochorema K.Schum. from Kalimantan, Indonesia [H. Funakoshi s.n. (MBK)] was found to be embedded within Boesenbergia.

Haplochorema $($ haplo $=$ single, chorema $=$ room, referring to the supposedly unilocular ovary) was published in 1899 by Karl Moritz Schumann (1851-1904) as a new genus with four species. These were described from specimens collected by Odoardo Beccari (1843-1920) in Borneo. Schumann considered these similar to Kaempferia L., but were distinguished by what he perceived as a unilocular ovary 
with basally affixed ovules. Five years later he added two more species from Borneo, bringing the total to six (Schumann, 1904). Theodoric Valeton (1855-1929) reviewed Haplochorema and designated H. uniflorum K.Schum. as the type (Valeton, 1918) (Fig. 1, 2). In the same discussion, he decided that the earlier published Kaempferia decus-silvae Hallier $\mathrm{f}$. was the same species, combined it as Haplochorema decussilvae (Hallier f.) Valeton (Fig. 3C, D) and made H. uniflorum a synonym. He was not convinced after studying specimens of Haplochorema that Schumann's claim of a unilocular ovary was fully correct, but that it may have been a variable character based on a modified trilocular structure. He also thought that the genus might not "be maintained as a whole". In 1919, Isaac Henry Burkill (1870-1965) cited a living plant from Sumatra growing at the Botanic Gardens, Singapore, and published it as a new species, Haplochorema sumatranum. The identification of the genus for this plant was based on its seemingly unilocular ovary, although he emphasised the flower was more similar to a Gastrochilus Wall. (Boesenbergia) than to a Kaempferia. Burkill (1923) suggested "the ovary of all the species in these three genera should be examined afresh".

Haplochorema had no significant mention again until 1972, when Burtt \& Smith transferred H. polyphyllum K.Schum. to Scaphochlamys polyphylla (K.Schum.) B.L.Burtt \& R.M.Sm. In 1980, Smith renamed Haplochorema oligospermum K.Schum. to Boesenbergia oligosperma (K.Schum.) R.M.Sm. and in 1982, H. gracilipes K.Schum. to B. gracilipes (K.Schum.) R.M.Sm.

Smith (1987) reviewed the Bornean Zingiberaceae and only two Haplochorema species remained, $H$. decus-silvae (with $H$. uniflorum as a synonym) and $H$. extensum K.Schum., but the latter Smith placed under "Imperfectly known species". Since Haplochorema sumatranum was known only from Sumatra, it was not addressed. Smith added two new species and a variety: Haplochorema magnum R.M.Sm. and H. pauciflorum R.M.Sm. with two varieties. Most important in her discussion was the confirmation by examination of recent collections of Haplochorema decus-silvae that "the ovary may also be trilocular or incompletely so; in all cases the partitioning can be seen." This type of abnormal or incompletely developed ovary can also be found in Boesenbergia and Scaphochlamys (Burtt \& Smith, 1964). Larsen et al. (1998) supported Smith's observations and published a description of Haplochorema stating that the "ovary [was] incompletely 3-locular."

With the issue of ovarian structure mostly resolved, the initial reason for retaining Haplochorema would seem to have ended at this juncture. Unfortunately, Smith was stymied by what she referred to as the "quadrate appearance" of the flower of Haplochorema decus-silvae, which had a deeply bilobed (or emarginate), flat labellum and a large, reflexed anther crest, similar to some Kaempferia (Fig. 3A, B). In her estimation, this character state was taxonomically more important than the singleflowered, distichous bracts, and basipetalous flowering sequence (top to bottom) found only in Boesenbergia. Although some Kaempferia, such as K. elegans (Wall.) Baker, had seemingly similar flowers, the bracts are essentially spiral with acropetalous flowering (bottom to top). Smith stated "The choice is to amend Boesenbergia to include species with quadrate flowers or to retain Haplochorema." The prioritisation 

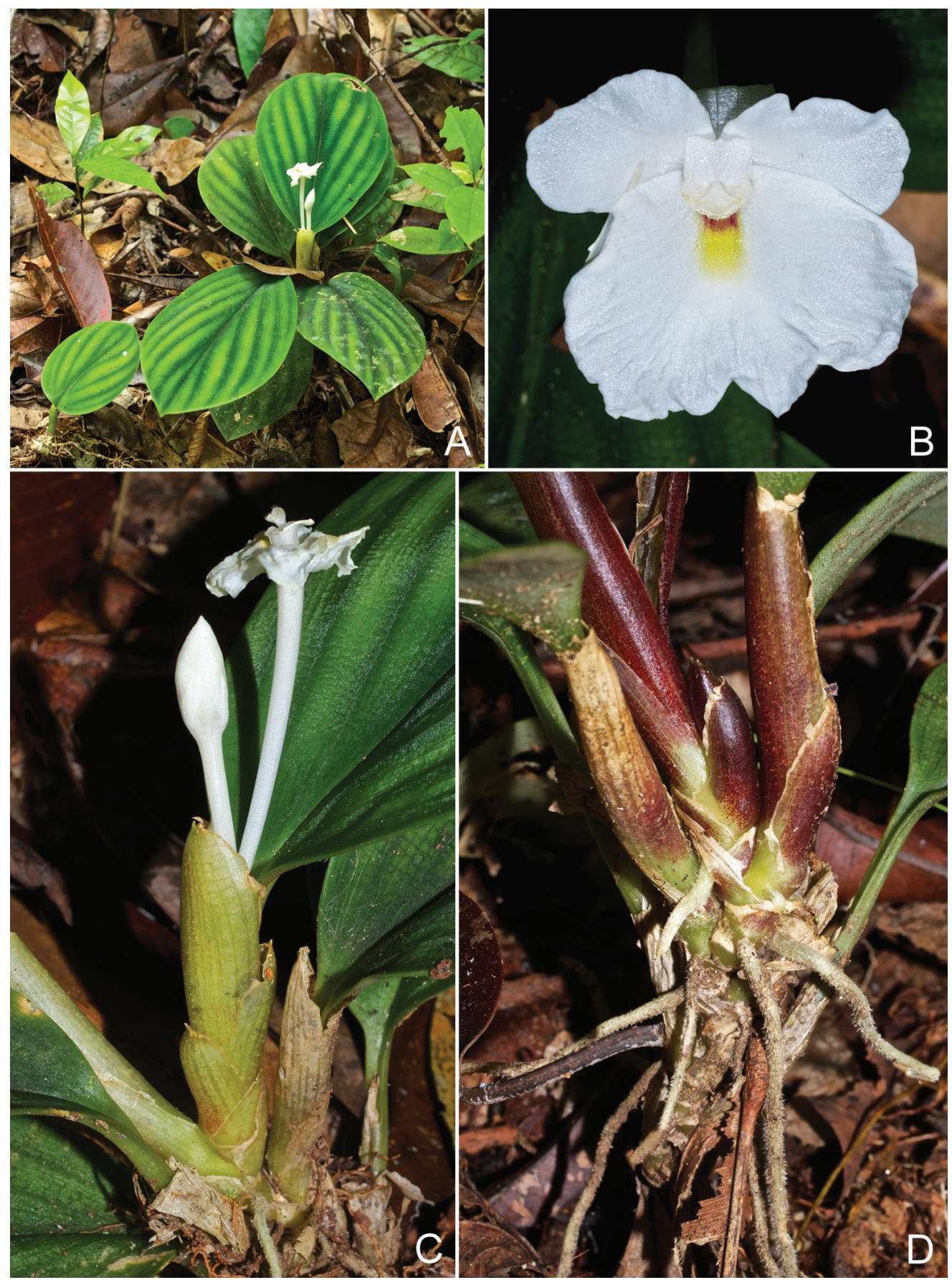

Fig. 1. Boesenbergia uniflora (K.Schum.) Ardiyani \& Mood in Sarawak. A. Plants. B. Flower. C. Inflorescence. D. Rhizome. (Photos: J. Mood). All from J. Mood \& Ooi Im Hin 3415/ SAR M3415. (Photos: J. Mood) 


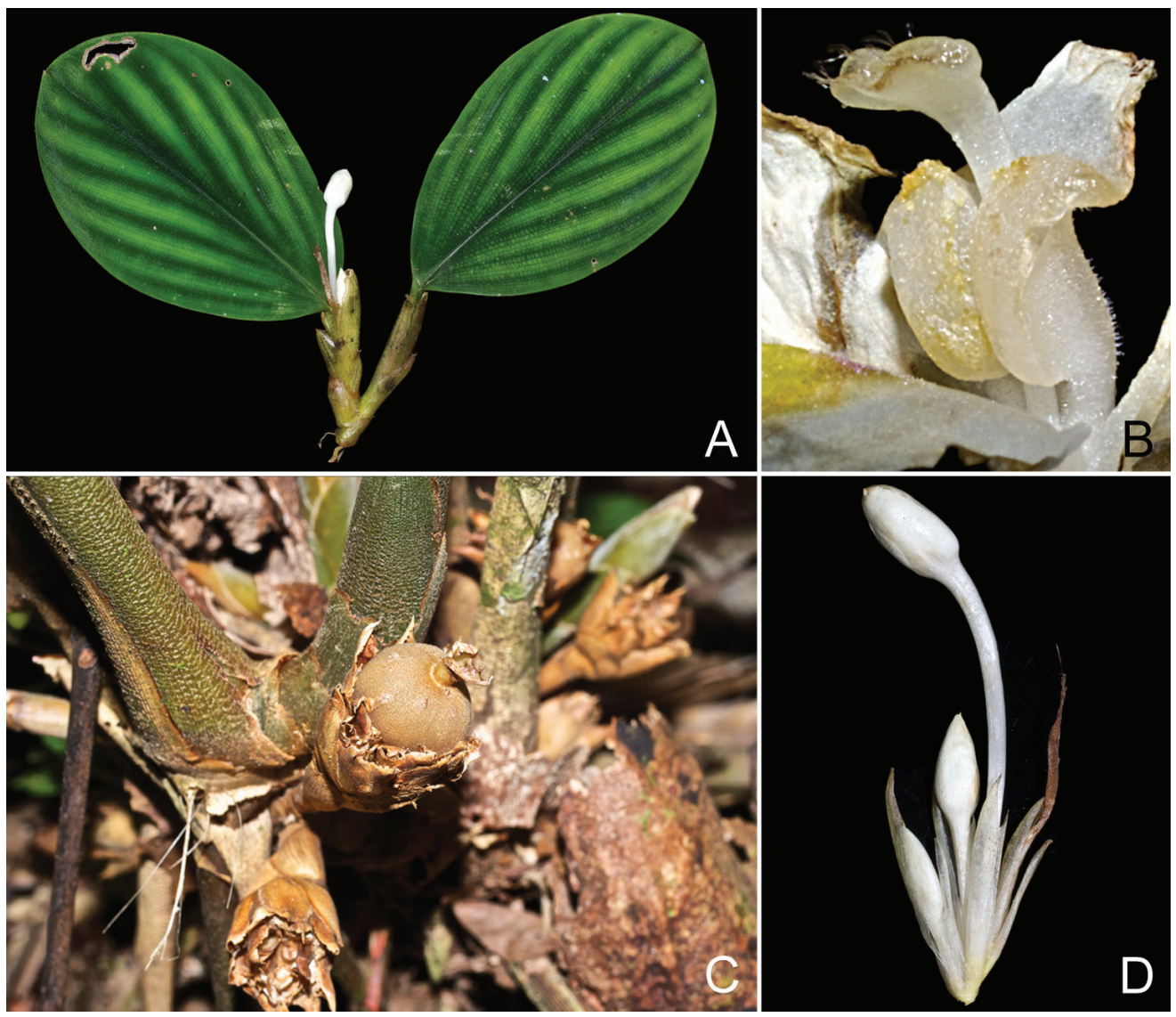

Fig. 2. Boesenbergia uniflora (K.Schum.) Ardiyani \& Mood in Sarawak. A. Single-leafed plant elements. B. Anther and stigma. C. Seed capsule. D. Inflorescence (dissected). All from $J$. Mood \& Ooi Im Hin 3415/ SAR M3415. (Photos: J. Mood)

of floral characters over inflorescence structure and flowering habit is not without precedent in Smith's approach. Larsen \& Smith (1972) faced a similar decision as whether to describe a new taxon as a Boesenbergia or as a Caulokaempferia K.Larsen. Although this particular taxon had the distichous bracts and basipetalous flowering of a Boesenbergia, its flattened, non-saccate flower form was considered more significant and thus they named it Caulokaempferia alba K.Larsen \& R.M.Sm. Recent molecular phylogenetic analyses show that labellum form is less significant in Boesenbergia systematics than inflorescence structure and flowering sequence, and as a consequence this species was transferred to Boesenbergia (Mood et al., 2014).

Sakai \& Nagamasu (2006a) transferred Gastrochilus latilabrus Valeton to Haplochorema based primarily on its bilobed labellum even though Valeton (1918) had clearly described the species as having a trilocular ovary. Additionally, Boesenbergia gracilipes was transferred to Scaphochlamys gracilipes (K.Schum.) S.Sakai \& Nagam. Since then, to our knowledge, no new information concerning Haplochorema has been published. 


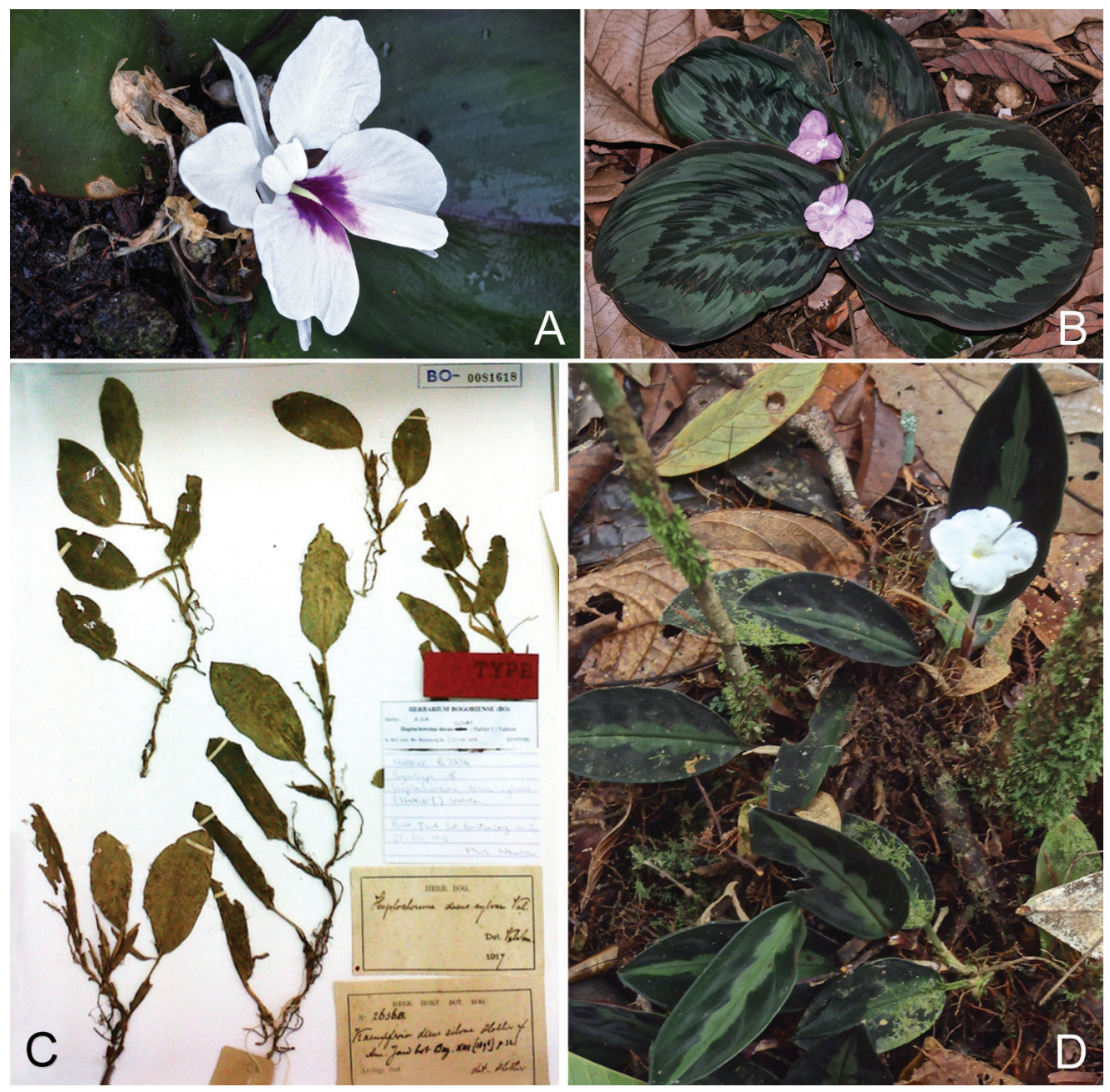

Fig. 3. A. Flower of Kaempferia galanga L. B. Plants of Kaempferia pulchra Ridl. C. Lectotype of Boesenbergia decus-silvae (Hallier f.) Ardiyani \& Mood. (BO). D. Plant of B. decus-silvae in Kalimantan. No associated specimens for 3A, B. \& D. (Photos: A \& B, J. Mood; C \& D, M. Ardiyani)

With this historical information, it was clear that the validity of Haplochorema as a morphologically distinct genus has been in question for some time. Now, with phylogenetic evidence indicating its affinity to Boesenbergia, we re-examine the taxonomy of Haplochorema and Boesenbergia. 


\section{Materials and methods}

\section{Morphology}

Living plants of Haplochorema, including the type, were studied (in situ and ex situ) by JDM in Sarawak, Malaysia (2014), while MA did similar research in Kalimantan, Indonesia (2013-present). In both situations, the plant morphology and ecology were examined and documented. Some of the key characters studied were vegetative habit, inflorescence and floral development, and floral form to include the ovary and fruit. Photographs of living plants at RBGE of Haplochorema pauciflorum R.M.Sm. (RBGE Acc. No. 20110241) along with many photographs provided by P. Boyce (USM) were also studied. Additionally, all available specimens of Haplochorema were examined at BO, E, K, L, SING, and SAR either in-hand or in some cases, downloaded from herbarium websites. Due to the delicate nature, poor condition or lack of floral portions of the majority of herbarium specimens, examination of the dried, miniscule ovaries was deemed impractical.

\section{Molecular phylogeny}

Seven leaf tissue samples of Haplochorema were dried and stored in silica gel for subsequent DNA extraction. DNA extraction and analytical methods follow Mood et al. (2013). The nuclear ribosomal ITS (nrITS) region was amplified using the plant specific primers developed by Prince (2010):1 8S-F (CGATTGAATGGTCCGGTGAAG) and 26S-R (AGGACGCTTCTACAGACTACAA). The plastid trnK region was amplified in two parts, the first using either 1F (CTCAACGGTAGAGTACTCG; Manos \& Steele, 1997) and mIR (CGTTTCACAAGTACTGAACTA) or 1F and 1235R (TATACTAATACCCCACYCC). The second half was amplified using mIF (GTTCAGTACTTGTGAAACGTT; Kress et al., 2002) and 2R (AACTAGTCGGATGGAGTAG; Steele \& Vilgalys, 1994). Data were collected on an ABI Genetic Analyzer (ThermoFisher Scientific) and edited in Sequencher v4.9 (Gene Codes Corporation). Consensus sequences were aligned manually in Se-Al (Rambaut, 1996) along with sequences for Boesenbergia and representative other Zingiberaceae genera. A list of samples and GenBank accession numbers are provided in Appendix 2. Maximum parsimony (MP) analyses were run in PAUP* (version 4.0b10; Swofford, 2002) for each genomic data partition independently and in combination. Heuristic search methods (1000 random addition replicates; tree bisection \& regrafting) were employed saving all shortest trees. Branch support was estimated using parsimony bootstrap (BS) in PAUP* under similar heuristic search methods (1000 bootstrap replicates of 100 random addition replicates, saving a maximum of 10 trees per random addition replicate). Maximum likelihood (ML) analyses of the combined dataset were also run in PAUP*, using the best-fit model identified by jModeltest version 2.1.6 (Darriba et al., 2012; Guindon \& Gascuel, 2003). Posterior probabilities (PP) for tree branches were estimated using Bayesian inference (BI; one million generations) as estimated in MrBayes 3.2.6 (Ronquist et al., 2011) via the CIPRES portal (Miller et al., 2010). 


\section{Results and discussion}

\section{Taxonomy}

The Haplochorema species around H. uniflorum are evergreen, perennial herbs found in tropical, wet evergreen forests at elevations normally below $300 \mathrm{~m}$. The plant maintains itself throughout the year by cyclic, rhizomatous growth on which new shoots or "elements" (Holttum, 1950) are produced. Each element produces at least one or more leafless sheaths, followed by one or two leaves. The inflorescence is produced at the terminus of the rhizome, normally at the base of the petiole. This element in turn will produce another element at a node below the petiole. In some species, such as Haplochorema pauciflorum, a new branch can form anywhere on the rhizome at a node. This new branch, formed at an angle, grows in a different direction from the parent stem. Over time, given suitable conditions, the resultant plant can cover a small area. This growth habit is very similar to many Scaphochlamys species (Searle, 2010) and evergreen Boesenbergia species, especially those of Borneo such as B. ischnosiphon S.Sakai \& Nagam. and B. lambirensis S.Sakai \& Nagam. (Sakai \& Nagamasu, 2006b).

The inflorescence structure of Haplochorema is typified by a very short peduncle, distichous bract arrangement on a short rachis, one flower per bract and a basipetalous flowering sequence (Smith, 1987; Larsen et al., 1998; pers. obs. JDM, MA). This morphology is very similar to Boesenbergia species. The top to bottom flowering sequence appears to have been first mentioned by Valeton (1918) and is easily recognised on the original watercolour of Boesenbergia pulcherrima (Wall.) Kuntze (Wallich, 1829), the type for the genus. The number of flowers reported per spike in Haplochorema varies from c. 10 in $H$. magnum to as few as 3-4 in $H$. pauciflorum (Smith, 1987). For Haplochorema uniflorum, field observations show most inflorescences have 3-5 flowers, thus the specific epithet is a misnomer.

Based on descriptions, photographs, and field observations the flowers of all species (except Haplochorema sumatranum) are white with a green-yellow spot at the throat opening that suggests a nectary guide. An identical pattern occurs in Boesenbergia alba (K.Larsen \& R.M.Sm.) Mood \& L.M.Prince. In some species two parallel red lines are noticeable in the throat. The flower's plane view can be semi-quadrate or less so with an emarginate apex. Each of the lateral staminodes are approximately half the size of the labellum. The stigma is large with a broad, open ostiole. As the flower senesces, the stigma moves downward toward the labellum from its near vertical position as in many Boesenbergia species (Mood et al., 2013). The labellum surface of Haplochorema is iridescent indicating that the epidermal cells are most likely conical. An iridescent sparkle can be more attractive to bees than noniridescent flowers (Baumann et al., 2007). This character also occurs in various species of Boesenbergia and Scaphochlamys as well as in Haniffia albiflora K.Larsen \& Mood. As mentioned, Smith had difficulty in taxonomically resolving the non-saccate flowers of Haplochorema as being another evolutionary form of Boesenbergia. In fact, Boesenbergia flowers have a broad range of three-dimensional shapes from very saccate [B. pulcherrima (Wall.) Kuntze] to nearly flat [B. loerzingii (Valeton) K.Larsen 
ex M.F.Newman, Lhuillier \& A.D.Poulsen] or flat as in B. alba (Fig. 4). As a note, it has been observed in Sarawak that pollination of Haplochorema species occurs at night by small wasps (pers. com. Ooi Im Hin, USM).

When Schumann (1899) described four ginger species in a new genus, Haplochorema, he based the decision primarily on their having a unilocular ovary. More recent observations have shown this condition to be the result of an incomplete development of a trilocular ovary (Smith, 1987). This was also reported for Scaphochlamys kunstleri (Baker) Holttum by Kirchoff (1998). In that case, Kirchoff studied the floral development and concluded that this species, although exhibiting a "uni-/trilocular condition [had] evolved from a strictly trilocular condition." Although no intensive study has been done on Haplochorema, the previously mentioned observations by Smith provide good circumstantial evidence of the same situation. Sakai \& Nagamasu (2006a) agreed when they stated, "this character [unilocular ovary] is not diagnostic for the genus [Haplochorema] because the ovary may also be trilocular or incompletely partitioned." Holttum (1950) also reported that certain species of Boesenbergia, Kaempferia and Scaphochlamys can have functional, unilocular ovaries, but most are trilocular. For now, without further investigation using floral development protocols, it appears that in Haplochorema the trilocular ovary is the basic structure, but under certain circumstances the septa do not completely develop yet produce a capsule and viable seed. During observations of living plants in situ, various stages of ovary development from flower opening to senescence were examined in Haplochorema uniflorum. In most cases the ovary was trilocular, but in a few samples, the septa were not fully developed. The mature fruit as seen in Fig. $2 \mathrm{C}$ was trilocular with viable seed. Observations in other species showed similar results.

When each of the currently recognized Haplochorema species was initially evaluated, $H$. sumatranum appeared morphologically different from the other species with a sub-rotund, bifid labellum with a broad, yellow apex, indicating it was a Boesenbergia. Burkill identified this taxon based on observations of a living plant at the Singapore Botanic Gardens, M. Nur 7258 (SING[SING0155289]). As noted above, he was not very certain about the validity of Schumann's genus nor his own placement of this taxon. In this light, M. Nur 7258 was closely scrutinized. Accompanying the vegetative specimen was a floral drawing with colour notes and two well-preserved flowers. The drawing showed a complete flower with poricidal dehiscence of the thecae. This form of dehiscence has only been found in several Boesenbergia, one of which is $B$. loerzingii also from Sumatra. In the final analysis, the protologues and types of these two species compared very well, thus Haplochorema sumatranum is reduced here into synonymy with Boesenbergia loerzingii (Appendix 1).

\section{Phylogeny}

The MP phylogenetic analysis of both the nuclear and chloroplast data sets are in agreement regarding the position of Haplochorema. ITS analyses produced 78 shortest trees based on 187 potentially phylogenetically informative characters (PPIC). Two clades with Boesenbergia taxa are retrieved. The Boesenbergia sensu stricto clade (87\% BS) includes its type B. pulcherrima (Wall.) Kuntze, and the other includes 

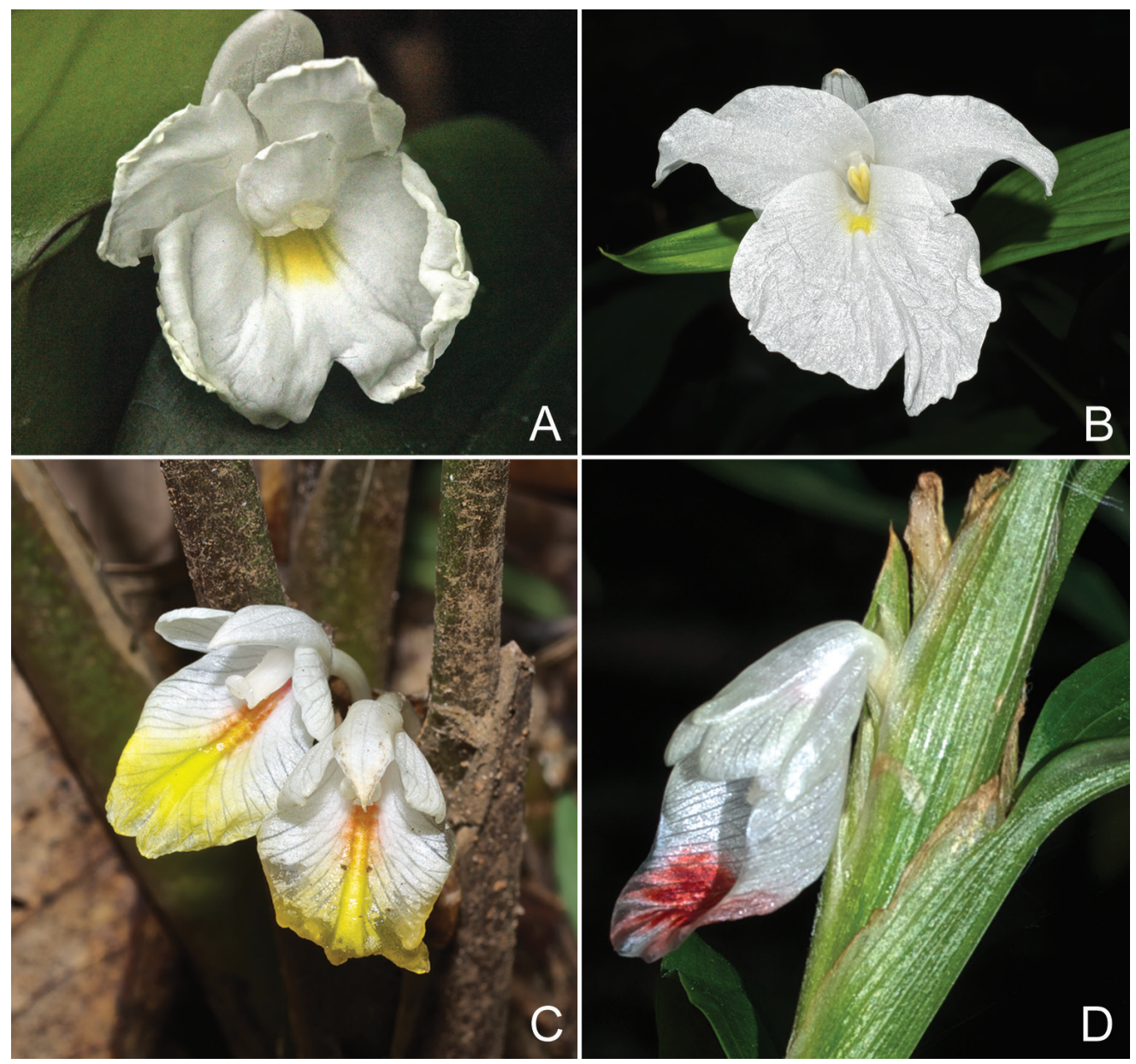

Fig. 4. Boesenbergia flower diversity. A. Boesenbergia uniflora from Sarawak. B. Boesenbergia alba (K.Larsen \& R.M.Sm.) Mood \& L.M.Prince from Thailand. C. Boesenbergia loerzingii (Valeton) K.Larsen ex M.F.Newman, Lhuillier \& A.D.Poulsen from Indonesia. D. Boesenbergia pulcherrima (Wall.) Kuntze from Thailand. (Photos: J. Mood).

three included species of Boesenbergia as well as all Haplochorema accessions (100\% BS). The seven Haplochorema samples form a monophyletic clade with strong $(96 \%)$ bootstrap support, but that clade is embedded within a clade with Boesenbergia species. Specifically, Boesenbergia rotunda (L.) Mansf. is sister (71\% BS) followed by B. clivalis (Ridl.) Schltr. (98\% BS), and B. ochroleuca (Ridl.) Schltr. (94\% BS). Relationships among the Haplochorema samples were not strongly supported. The $\operatorname{trnK}$ analysis was based on 125 PPIC and generated 33692 shortest trees. Results of the trnK analyses showed the same three Boesenbergia taxa as closest relatives to all Haplochorema samples, although in slightly different order, and with bootstrap values ranging from less than $50 \%$ to $85 \%$. The combined matrix (312 PPIC) analysis produced 1183 shortest trees with overall topology similar to the independent analysis phylogenies. 
Haplochorema samples formed a monophyletic clade with strong support (98\% BS) but were nested within the genus Boesenbergia as shown in the phylogram of Fig. 5 . The position of Haplochorema within Boesenbergia was also strongly supported by a grade of three nodes with BS values of 95, 95, and 100\% (successively). Analyses of DNA sequence data show the affinity of Haplochorema with Boesenbergia. Although monophyly of Boesenbergia was not strongly supported by bootstrap, all MP trees recovered showed the two clades as sister. Maximum likelihood model selection by jModelTest indicated the General Time Reversible model (GTR) was the best fit for the combined data set regardless of the criterion (Akaike Information Criterion, Bayesian Inference Criterion, Decision Theory). Model selection and parameters were identical for all. Selected parameters were as follows: $\mathrm{GTR}+\mathrm{I}+\mathrm{G} ; \mathrm{K}=82$; base frequencies $\mathrm{A}=0.3319, \mathrm{C}=0.1584, \mathrm{G}=0.1706, \mathrm{~T}=0.3391$; transition matrix $[\mathrm{AC}]=1.1436$, $[\mathrm{AG}]=2.3404,[\mathrm{AT}]=0.5045,[\mathrm{CG}]=1.1008,[\mathrm{CT}]=4.4580,[\mathrm{GT}]=1.0000$; proportion of invariant sites $=0.4570$; gamma shape $=0.6820$. A single $\mathrm{ML}$ tree was recovered and was identical in branching pattern (and nearly identical in relative branch lengths) to the phylogram shown in Fig. 5. Posterior probabilities were estimated from the stable portion of the one million generation distribution. The stable region was identified as the region where the splits frequencies had a lower than 0.01 standard deviation. This occurred approximately 250,000 generations into the run. Results from three separate MrBayes runs were pooled to create the PP estimates. For simplicity, PP are provided on the MP tree in Fig. 5. Posterior probabilities were generally high on those branches with high BS values. Notable exceptions were restricted to branches outside Boesenbergia such as the PP support for relationships along the backbone of the tree between Hedychium and Haniffia where BS support was lacking.

There was no strongly supported evidence of para- or polyphyly for Boesenbergia in the molecular phylogenetic trees whether data were analysed under parsimony or likelihood criteria. The monophyly of Boesenbergia has been shown elsewhere, albeit with weak support (Mood et al., 2014).

\section{Discussion}

The phylogenetic framework shows a clear relation of Boesenbergia and Haplochorema, and yields strong support for two clades, I. including the type of Boesenbergia and several of its taxa (87\% BS/1.00 PP) and II. including several Boesenbergia species as well as all species of Haplochorema (100\% BS/1.00 PP) in a nested monophyletic clade (98\% BS/1.00 PP). The relation between the two Boesenbergia clades I and II is unresolved, and two solutions are possible to resolve this nomenclatural challenge: (1) The three Boesenbergia taxa in the clade II could be merged into Haplochorema, together with Boesenbergia taxa that share their morphology; or (2) Haplochorema could be merged into Boesenbergia. The phylogenetic framework cannot be used to choose between these two options, and an objective assessment of the morphology of these taxa is necessary. Two arguments in favour of merging Haplochorema into Boesenbergia would be nomenclatural parsimony and taxonomic confidence, i.e., combining all Haplochorema taxa in Boesenbergia is straightforward, but establishing through morphology and phylogenetic studies what other taxa in Boesenbergia, that are 


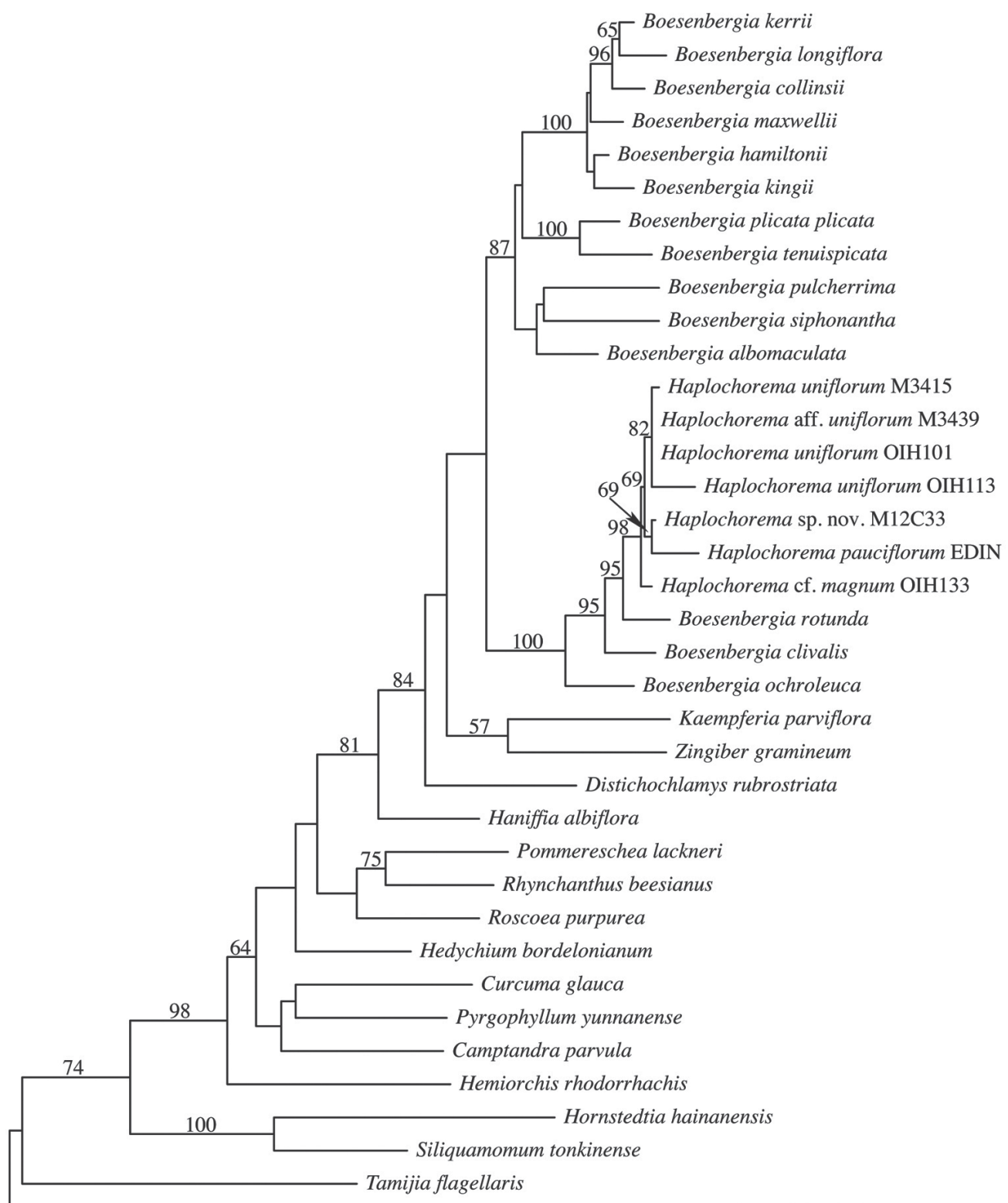

Siphonochilus kirkii

10 changes

Fig. 5. Phylogram of one of the shortest maximum parsimony trees from analyses of combined ITS and $\operatorname{trnK}$ sequences to evaluate the position of Haplochorema in the family Zingiberaceae. Numbers above the branches are parsimony bootstrap / posterior probability values. Haplochorema accessions are marked with sample number for ease of identification (Appendix 2). 
not included in the current study, should be merged into Haplochorema would require a lot of work. Characters that are shared by all Boesenbergia and Haplochorema taxa are: single-flowered, having distichous bracts, and a basipetalous flowering sequence. Boesenbergia have trilocular ovaries, but it has been shown during past and present investigations that in Haplochorema, the normal ovarian form is also trilocular, albeit, not always with completely developed septa. Characters shared by Boesenbergia in clade I are presence of an androecial cup, absence of an anther crest, being mostly deciduous, having mostly saccate labellae but ranging from flat to clearly saccate, and having mostly $2 \mathrm{n}=20$ chromosomes but ranging from 18 to 36 (Goldblatt \& Johnson, 1991; Eksomtramage \& Boontum, 1995; Eksomtramage et al., 2002; Mood et al., 2018; Mood et al., 2019). Characters shared by Boesenbergia and Haplochorema in clade II are absence of an androecial cup, presence of an anther crest, and mostly having flat labellae. The chromosome counts of taxa in clade II are $2 n=24$, but counts are available only for two Boesenbergia taxa, B. rotunda (L.) Mansf. and B. ochroleuca (Ridl.) Schltr. (Mandáková, in prep.). Furthermore, Haplochorema taxa are evergreen, whereas clade II Boesenbergia taxa are mainly deciduous. Haplochorema taxa also have a "quadrate appearance" of the flower with deeply bilobed (or emarginate), flat labellum and a large, reflexed anther crest. The morphological characters are not unambiguous and do not provide an easy solution to choosing between the two possible options. However, previous molecular phylogenetic analyses of Boesenbergia (Mood et al., 2014) show that labellum form is less significant in Boesenbergia systematics than inflorescence structure and flowering sequence, characters that are shared by all Boesenbergia and Haplochorema taxa.

\section{Conclusions}

The overall morphology of Haplochorema is very similar to evergreen Boesenbergia. The phylogenetic framework shows a clear relation of Boesenbergia and Haplochorema but does not provide support for either merging Haplochorema into Boesenbergia or merging a part of Boesenbergia into Haplochorema. Haplochorema and the two clades that include Boesenbergia taxa have both shared and clade-specific characters. Based on the shared inflorescence characters of being single-flowered, having distichous bracts, and a basipetalous flowering sequence, the weak support for monophyly found in Mood et al. (2014), as well as nomenclatural parsimony and taxonomic confidence, we propose the merger of Haplochorema and Boesenbergia.

ACKNOWLEDGEMENTS. We would like to thank P.C. Boyce (USM), H. Funakoshi (BRIC), and M. Newman (E) for leaf samples; Y.Y. Sam (KEP) for discussions on Scaphochlamys; the Field Museum (F), Chicago, USA, for use of laboratory facilities; BO, E, K, L, SING, and SAR for herbarium facilities; and the reviewers for their time and diligence. A special acknowledgement to Ooi Im Hin (USM) for his assistance in the field to find living specimens and later, samples and photography. The second author would like to thank Singapore Botanic 
Gardens for the SBG Fellowship she obtained to examine the herbarium specimens in SING herbarium. Colour plates were created by Linda Ann Vorobik (Berkeley, USA).

\section{References}

Baumann, K., Perez-Rodriquez, M., Bradley, D., Venail, J, Bailey, P., Jin, H., Koes, R., Roberts, K. \& Martin, C. (2007). Control of cell and petal morphogenesis by R2R3 MYB transcription factors. Development 134: 1691-1701.

Burkill, I.H. (1919). Some notes on the pollination of flowers in the Botanic Gardens, Singapore, and in other parts of the Malay Peninsula. Gard. Bull. Straits Settlem. 2: 165-176.

Burkill, I.H. (1923). Haplochorema sumatranum. Gard. Bull. Straits Settlem. 3: 18-19.

Burtt, B.L. \& Smith, R.M. (1964). A new species of Zingiberaceae from Sarawak. Trans. Bot. Soc. Edinburgh 39: 502-511.

Burtt, B.L. \& Smith, R.M. (1972). Notes on Malesian Zingiberaceae. Notes Roy. Bot. Gard. Edinburgh 31: 307-316.

Darriba, D., Taboada, G.L., Doallo, R. \& Posada, D. (2012). jModelTest 2: more models, new heuristics and parallel computing. Nature Methods 9: 772.

Eksomtramage, L. \& Boontum, K. (1995). Chromosome counts of Zingiberaceae. Songklanakarin J. Sci. Technol. 17: 291-297.

Eksomtramage, L., Sirirugsa, P., Jivanit, P. \& Maknoi, C. (2002). Chromosome counts of some Zingiberaceous species from Thailand. Songklanakarin J. Sci. Technol. 24: 311-319.

Goldblatt, P. \& Johnson, D.E. (1991). Index to plant chromosome numbers 1988-1989. Monographs in Systematic Botany, No. 40. Missouri, USA: Missouri Botanical Garden.

Guindon, S. \& Gascuel, O. (2003). A simple, fast and accurate method to estimate large phylogenies by maximum-likelihood. Syst. Biol. 52: 696-704.

Hallier, H. (1896). Neue und bemerkenswerte Pflanzen aus dem Malaiisch-Papuanischen Inselmeer. Ann. Jard. Bot. Buitenzorg 13: 276-357.

Holttum, R.E. (1950). The Zingiberaceae of the Malay Peninsula. Gard. Bull. Singapore 13: $82-105$.

Kirchoff, B.K. (1998). Inflorescence and flower development in the Hedychieae (Zingiberaceae): Scaphochlamys kunstleri (Baker) Holttum. Int. J. Pl. Sci. 159: 261-274.

Kress, W.J., Prince, L.M. \& Williams, K.J. (2002). The phylogeny and a new classification of the gingers (Zingiberaceae): Evidence from molecular data. Amer. J. Bot. 89: 16821696.

Larsen, K. \& Smith, R.M. (1972). Notes on Caulokaempferia. Notes Roy. Bot. Gard. Edinburgh 31: 287-295.

Larsen, K., Lock, J.M., Maas, H. \& Maas, P.J.M. (1998). Zingiberaceae. In: K. Kubitzki (ed.) The Families and Genera of Vascular Plants, vol. 4, Flowering plants - Monocotyledons. Alismatanae and Commelinanae (except Gramineae), pp. 474-495. Berlin: Springer Verlag.

Manos, P.S. \& Steele, K.P. (1997). Phylogenetic analyses of "higher" Hamamelididae based on plastid sequence data. Amer. J. Bot. 84: 1407-1419.

Miller, M.A., Pfeiffer, W. \& Schwartz, T. (2010). Creating the CIPRES Science Gateway for inference of large phylogenetic trees. In: Proceedings of the Gateway Computing Environments Workshop (GCE), pp. 1-8. New Orleans, LA: IEEE. 
Mood, J.D., Prince, L.M., Veldkamp, J.F. \& Dey, S. (2013). The history and identity of Boesenbergia longiflora (Zingiberaceae) and descriptions of five related new taxa. Gard. Bull. Singapore 65: 47-95.

Mood, J.D., Veldkamp, J.F., Dey, S. \& Prince, L.M. (2014). Nomenclatural changes to Zingiberaceae: Caulokaempferia is a superfluous name for Monolophus and Jirawongsea is reduced to Boesenbergia. Gard. Bull. Singapore 66: 215-231.

Mood, J.D., Tran, H.D., Prince, L.M. \& Veldkamp, J.F. (2018). Taxonomy of Boesenbergia parvula (Zingiberaceae) with new synonymy. Thai Forest Bull., Bot. 46: 10-24.

Mood, J.D., Veldkamp, J.F., Mandáková, T., Prince, L.M. \& de Boer, H.J. (2019). Three new species of Boesenbergia (Zingiberaceae) from Thailand and Lao P.D.R. Gard. Bull. Singapore 71: 473-495.

Prince, L.M. (2010). Phylogenetic relationships and species delimitation in Canna (Cannaceae). In: Seberg, O., Petersen, G., Barfod, A.S. \& Davis, J.I. (eds) Diversity, phylogeny, and evolution in the Monocotyledons, pp. 307-331. Aarhus: Aarhus University Press.

Rambaut, A. (1996). Se-Al (v2.0a11) Sequence Alignment Editor. http://tree.bio.ed.ac.uk/ software/seal/._Accessed 3 Dec. 2013.

Ronquist, F., Huelsenbeck, J. \& Teslenko, M. (2011). MrBayes version 3.2 Manual: Tutorials and Model Summaries. Available from http://mrbayes.sourceforge.net/.

Sakai, S. \& Nagamasu, H. (2006a). Systematic studies of Bornean Zingiberaceae V. Zingiberoideae of Lambir Hills, Sarawak. Blumea 51: 95-115.

Sakai, S. \& Nagamasu, H. (2006b). Notes on inflorescence structure of Boesenbergia (Zingiberaceae). Acta Phytotax. Geobot. 57: 107-111.

Schumann, K. (1899). Monographie der Zingiberaceae von Malaisien und Papuasien. Bot. Jahrb. Syst. 27: 259-350.

Schumann, K. (1904). Zingiberaceae. In: Engler, A. (ed.) Das Pflanzenreich IV(46), Heft 20, pp. 1-458. Leipzig: Engelmann.

Searle, R.J. (2010). The genus Scaphochlamys (Zingiberaceae - Zingibereae): a compendium for the field worker. Edinburgh J. Bot. 67: 75-121.

Smith, R.M. (1980). Notes on Zingiberaceae. Notes Roy. Bot. Gard. Edinburgh 38: 19-21.

Smith, R.M. (1982). Systematic notes on, and new species of Zingiberaceae of the Gunung Mulu National Park. Bot. J. Linn. Soc. 85: 36-73.

Smith, R.M. (1987). A review of Bornean Zingiberaceae: III (Hedychieae). Notes Roy. Bot. Gard. Edinburgh 44: 203-232.

Steele, K.P. \& Vilgalys, R. (1994). Phylogenetic analysis of Polemoniaceae using nucleotide sequences of the plastid gene matK. Syst. Bot. 19: 126-142.

Swofford D.L. (2002). PAUP*: phylogenetic analysis using parsimony (*and other methods), vers. 4.0b10. Sunderland, Massachusetts, USA: Sinauer Associates, Inc.

Valeton, T. (1918). New notes on the Zingiberaceae of Java and Malaya. Bull. Jard. Bot. Buitenzorg, ser. II, 27: 1-166.

Veldkamp, J.F. (2013). Nomanclatural notes on Boesenbergia Kuntze (Zingiberaceae). Philipp. J. Sci. 142: 215-221.

Wallich, N. (1829) Gastrochilus. Plantae Asiaticae Rariores, vol. 1, pp. 22-23. London: Treuttel \& Würz. 
Appendix 1. New Boesenbergia combinations and synonymy.

Boesenbergia Kuntze, Revis. Gen. Pl. 2: 685 (1891). - Gastrochilus Wall., Pl. Asiat. Rar. 1: 22 (1829). TYPE: Boesenbergia pulcherrima (Wall.) Kuntze, lectotype designated by Holttum (1950: 107).

Haplochorema K.Schum., Bot. Jahrb. Syst. 27: 331 (1899). - TYPE: Haplochorema uniflorum K.Schum., lectotype designated by Valeton (1918: 115).

1. Boesenbergia decus-silvae (Hallier f.) Ardiyani \& Mood, comb. nov. Kaempferia decus-silvae Hallier f., Ann. Jard. Bot. Buitzenzorg 13: 321, t. 27, f. 4 (1896). Haplochorema decus-silvae (Hallier f.) Valeton, Bull. Jard. Bot. Buitenzorg II, 27: 116 (1918). - TYPE: Indonesia, Kalimantan, Liang Gatang Mts, Hallier $2636 b$ (lectotype L [L.122322 spirit], designated by Mood et al. (2014: 228); isolectotype BO [0081618]).

Notes. Placed in Kaempferia L. sect. Monolophus by Hallier (1896).

2. Boesenbergia extensa (K.Schum.) Veldk. \& Mood, comb. nov.

Haplochorema extensum K.Schum., Bot. Jahrb. Syst. 27: 333 (1899). - TYPE: Malaysia, Sarawak, Batang Lupar, Gunong Tiang Mts, Beccari PB 3218 (lectotype FI [FI008267], designated by Smith, 1987: 214).

3. Boesenbergia latilabrum (Valeton) Veldk. \& Mood, comb. nov.

Gastrochilus latilabrus Valeton, Bull. Jard. Bot. Buitenzorg II, 27: 99 (1918). - Haplochorema latilabrum (Valeton) S.Sakai \& Nagam., Blumea 51: 110 (2006). - TYPE: Indonesia, Borneo, Selebulan, Teputing, 1896-1897, Nieuwenhuis 872 (holotype BO).

4. Boesenbergia loerzingii (Valeton) K.Larsen ex M.F.Newman, Lhuillier \& A.D.Poulsen, Blumea Suppl. 16: 56 (2004). - Gastrochilus loerzingii Valeton, Bull. Jard. Bot. Buitenzorg II, 27: 94-95 (1918). - TYPE: Indonesia, Sumatra, Sibolangit, Lörzing 4812 (lectotype BO, designated here; isolectotype L [L0872579]).

Haplochorema sumatranum Burkill, Gard. Bull. Straits Settlem. 3: 18-19 (1923). - TYPE: Indonesia, Sumatra, Sibolangit, M. Nur 7258, cult in Hort. Bot. Sing. (holotype SING [SING0155289]).

Notes. Larsen erroneously designated Bünnemeyer 532 as a lectotype for Gastrochilus loerzingii Valeton in Larsen (1997), as noted by Veldkamp (2013) who revised all original material of Gastrochilus loerzingii and its varieties in BO and L. Veldkamp identified two collections by Lörzing (4812 and 5296), both collected in Sibolangit in 1917, as possible types, yet he annotated and published Lörzing 4812 as a holotype. As this work post-dates 2000 it cannot be considered to be an unintentional lectotypification. Here we formally designate Lörzing 4812 (BO) as the lectotype, a specimen which matches the diagnosis in Valeton (1918: 94).

5. Boesenbergia magna (R.M.Sm.) Veldk. \& Mood, comb. nov.

Haplochorema magnum R.M.Sm., Notes Roy. Bot. Gard. Edinburgh 44: 214 (1987). - TYPE: Malaysia, Sarawak, 7th Division, B. Dema to S. Brearan, 28 August 1978, Burtt 11345 (holotype E [E00116368]; isotypes E [E00389362, E00116369], K [K000255407], SAR). 
Notes. In the protologue Smith does not indicate which of the two sheets and single spirit collection of Burtt 11345 in E should be designated as holotype. However, only Burtt 11345 [E00116368] is annotated on the sheet by Smith as holotype, and this can be interpreted as being the intended holotype.

6. Boesenbergia pauciflora (R.M.Sm.) Veldk. \& Mood, comb. nov.

Haplochorema pauciflorum R.M.Sm., Notes Roy. Bot. Gard. Edinburgh 44: 213, t. 2 (1987).

- TYPE: Malaysia, Sarawak, 3rd Division, Melinau Community forest near Nanga Tunoh, 3 August 1967, Burtt \& Martin B4775, cult. RBG Edinburgh, July 1969, C6737 (holotype E [E00116372]).

7. Boesenbergia pauciflora var. bullata (R.M.Sm.) Veldk. \& Mood, comb. nov.

Haplochorema pauciflorum var. bullatum R.M.Sm., Notes Roy. Bot. Gard. Edinburgh 44: 213, t. 2 (1987). - TYPE: Malaysia, Sarawak, 3rd Division, Hose Mts, gorge of S. Simpurai, 14 August 1967, Burtt \& Martin B4927, cult. RBG Edinburgh, March 1968 (holotype E [E00116376]; isotype SAR).

8. Boesenbergia uniflora (K.Schum.) Ardiyani \& Mood, comb. nov.

Haplochorema uniflorum K.Schum., Bot. Jahrb. Syst. 27: 332 (1899). - TYPE: Sarawak, 2nd Division, Batang Lupar, Tieng Ladschin, Beccari PB 3219 (lectotype K [K000255406], designated by Smith (1987: 212); isolectotypes FI [FI008266], P [P00686550]).

\section{Excluded taxa (accepted name in bold):}

1. Haplochorema gracilipes K.Schum., Bot. Jahrb. Syst. 27: 332 (1899). - Boesenbergia gracilipes (K.Schum.) R.M.Sm., Bot. J. Linn. Soc. 85: 43 (1982). - Scaphochlamys gracilipes (K.Schum.) S.Sakai \& Nagam., Blumea 51: 110 (2006). - TYPE: Malaysia, Sarawak, Gunung Walo, Beccari PB 2839 (lectotype K [K000255378], designated by Smith (1987: 221); isolectotypes FI [FI008268], P [P00686464].

Notes. Based on the Beccari type, the generic placement of this taxon has been reconfirmed by Y.Y. Sam (KEP, pers. com., 2013).

2. Haplochorema petiolatum K.Schum. in Engler \& Prantl, Pflanzenr. IV, 46 (Heft 20): 90 (1904). - Scaphochlamys petiolata (K.Schum.) R.M.Sm., Notes Roy. Bot. Gard. Edinburgh 44: 210 (1987). - TYPE: Malaysia, Sarawak, Mt Sunghi, Haviland 2026 (lectotype K [K000255347], designated by Smith (1987: 210)).

3. Haplochorema polyphyllum K.Schum., Bot Jahrb. Syst. 27: 332 (1899). - Scaphochlamys polyphylla (K.Schum.) B.L.Burtt \& R.M.Sm., Notes Roy. Bot. Gard. Edinburgh 31: 315 (1972). - TYPE: Malaysia, Sarawak, Lundu, Beccari PB 2324 (lectotype FI, designated by Burtt \& Smith, 1972: 315). 


\section{Taxa nomina inquirenda:}

1. Gastrochilus loerzingii Valeton var. bandarensis Valeton, Bull. Jard. Bot. Buitenzorg II, 27: 95 (1918). - TYPE: Sibulangit, above Bandar, 1000 m, Lörzing 1728 (holotype BO).

2. Gastrochilus loerzingii Valeton var. bencoolensis Valeton, Bull. Jard. Bot. Buitenzorg II, 27: 94 (1918). - TYPE: Bencoolen, on the western declivity of Talaman, 500 m, Bünnemeyer 532 (holotype BO).

3. Haplochorema platyphyllum K.Schum., Bot. Jahrb. Syst. 27: 333 (1899). - TYPE: Lost B duplicate of Beccari PB 3219 p.p.

Notes. Schumann refers to material found mixed with the type of Haplochorema uniflorum on the Berlin duplicate of Beccari PB 3219. The extant Beccari PB 3219 sheets in FI, K and P (see H. uniflorum above) do not have any material that fits the description. 
Appendix 2. GenBank accession numbers for Zingiberaceae species used in this study, listed by their accepted names. Format: identification, plant sample number sequences generated for this study (collector and voucher number, herbarium), ITS GenBank number/trnK GenBank number.

Boesenbergia albomaculata S.Q.Tong: M11C83 (J. Murata et al. 20050595K, MBK) KU159317/KU159408.

Boesenbergia clivalis (Ridl.) Schltr.: M11C127 (L.C. Keat s.n., UPM) KU159398/KU159409. Boesenbergia collinsii Mood \& L.M.Prince: M06P14 (J. Mood 12P171, holotype, BK) JX992751/JX992812.

Boesenbergia hamiltonii Mood, S.Dey \& L.M. Prince: M3017 (S. Dey NU53, holotype, CAL) JX992754/JX992815.

Boesenbergia kerrii Mood, L.M.Prince \& Triboun: M2044 (J. Mood \& P. Triboun 12P170, holotype, BK) JX992756/JX992817.

Boesenbergia kingii Mood \& L.M.Prince: M3074 (J. Mood \& P. Vatcharakorn 12P173, holotype, BK) JX992793/ JX992829.

Boesenbergia longiflora (Wall.) Kuntze: M11P48 (Kress 03-7305, US (sampled from living material of this collection)) JX992798/ JX992831.

Boesenbergia maxwellii Mood, L.M.Prince \& Triboun: M2032 (J. Mood \& P. Triboun 12P172, holotype, BK) JX992800, JX992833.

Boesenbergia cf. magna (R.M.Sm.) Veldk. \& Mood: OIH 133 (Ooi Im Hin OIH133, SAR) KU291109/KU291116.

Boesenbergia ochroleuca (Ridl.) Schltr.: M3116 (J. Mood \& P. Vatcharakorn 3116, BKF) KU159399/KU159410.

Boesenbergia pauciflora (R.M.Sm.) Veldk. \& Mood: (M. Newman 2459, E from living accession 20110241A at RBGE) KU291110/KU291117.

Boesenbergia plicata var. plicata (Ridl.) Holttum: M3177 (J. Mood \& Vatcharakorn 3177, BKF) JX992807/JX992840.

Boesenbergia pulcherrima (Wall.) Kuntze: M08P276 (J. Mood 08P276, BISH) X992809/ JX992748.

Boesenbergia rotunda (L.) Mansf.: M11P27 (J. Mood 11P27, BKF) KU159400/KU159411.

Boesenbergia siphonantha (King ex Baker) M.Sabu, Prasanthk. \& Škorničk.: M2056 (J. Mood \& P. Chalermglin 2056, BKF) KU159401/KU159412.

Boesenbergia sp. nov. (ined.): M12C33 (H. Funakoshi s.n., MBK) KU291111/KU291118.

Boesenbergia tenuispicata K.Larsen: M3292 (J. Mood 3292, BKF) KU159405/KU159416.

Boesenbergia uniflora (K.Schum.) Ardiyani \& Mood: M3415 (J. Mood \& Ooi Im Hin 3415, SAR) KU291112/KU291119.

Boesenbergia uniflora (K.Schum.) Ardiyani \& Mood: OIH 101 (Ooi Im Hin OIH101, SAR) KU291113/KU291120.

Boesenbergia uniflora (K.Schum.) Ardiyani \& Mood: OIH 113 (Ooi Im Hin OIH113, SAR) KU291114/KU291121.

Boesenbergia aff. uniflora (K.Schum.) Ardiyani \& Mood: M3439 (P. Boyce ZI-192, SAR) KU291115/KU291122.

Camptandra parvula (King ex Baker) Ridl.: (W.J. Kress 99-6328, US) AF478730/AF478830. Curcuma glauca (Wall.) Škorničk. (Listed in Genbank as Hitchenia glauca Wall.): (W.J. Kress 00-6743, US) AF478765/AF478864.

Distichochlamys rubrostriata W.J.Kress \& Rehse: (W.J. Kress 01-6848, US) AF478745/ AF478844. 
Haniffia albiflora K.Larsen \& Mood: (W.J. Kress 99-6370, US) AF478756/AF478855.

Hedychium bordelonianum W.J.Kress \& K.J.Williams: (W.J. Kress 99-6462, US) AF478757/ AF478856.

Hemiorchis rhodorrhachis K.Schum.: (M. Newman 861, E) AF478763/AF478863.

Hornstedtia hainanensis T.L.Wu \& S.J.Chen: (W.J. Kress 97-5769, US) AF478766/AF478865. Kaempferia parviflora Wall. ex Baker: M3087 (J. Mood 3087, BKF) KU159396/KU159407. Pommereschea lackneri Wittm.: (W.J. Kress 00-6739, US) AF478776/AF478877. Pyrgophyllum yunnanense (Gagnep.) T.L.Wu \& Z.Y.Chen: (W.J. Kress 00-6596, US) AF478777/AF478878.

Rhynchanthus beesianus W.W.Sm.: (W.J. Kress 97-5827, US) AF478784/AF478885.

Roscoea purpurea Sm.: (W.J. Kress 01-6953, US) AF478787/AF478888.

Siliquamomum tonkinense Baill.: (W.J. Kress 00-6802, US) AF478791/AF478892.

Siphonochilus kirkii (Hook.f.) B.L.Burtt: (W.J. Kress 94-3692, US) AF478794/AF478895.

Tamijia flagellaris S.Sakai \& Nagam.: (Kazuyuki S55, KYO) AF478797/AF478898.

Zingiber gramineum Noronha ex Blume: (W.J. Kress 96-5739, US) AF478800/AF478902. 
